\title{
A PSICOLOGIA SOCIAL COMO ESPECIALIDADE: UM DEBATE QUE CONTINUA
}

Esther Maria de M. Arantes

No ano de 2000, através da Resolução 014/ 00, o Conselho Federal de Psicologia instituiu o título profissional de Especialista em Psicologia, dispondo sobre as normas e os procedimentos para o respectivo registro do título. Foram aprovadas as seguintes especialidades: Psicologia Escolar e Educacional; Psicologia Organizacional e do Trabalho; Psicologia do Trânsito; Psicologia Jurídica; Psicologia do Esporte; Psicologia Hospitalar; Psicologia Clínica; Psicopedagogia; e Psicomotricidade. Posteriormente, através da Resolução 05/03, o CFP reconheceu a Psicologia Social como Especialidade em Psicologia, igualmente para fins de concessão e registro do título de Especialista. Tal decisão, longe de ser ponto pacífico entre os psicólogos, ensejou inúmeros questionamentos, a começar pelo próprio entendimento do que seja a Psicologia Social.

No III Encontro da ABRAPSO-Regional Rio "Práticas Sociais, Direitos Humanos e os Fazeres do Psicólogo", realizado nos dias 16, 17 e 18 de novembro de 2004, na UERJ, o tema "A Psicologia Social como Especialidade" foi debatido em Mesa Redonda composta por Odair Furtado, pesquisador visitante do Instituto de Psicologia da UNB e presidente do CFP na gestão 2001-2004; Cornelis Johannes van Stralen, professor do Departamento de Psicologia da UFMG e atual presidente da ABRAPSO; Neuza M. F. Guareschi, professora da PUCRS e presidente da ABRAPSO na gestão anterior e Heliana de Barros Conde Rodrigues, professora do Departamento de Psicologia Social e Institucional do Instituto de Psicologia da UERJ e Coordenadora do Curso de Especialização em Psicologia Jurídica.

O debate, bastante rico e elucidativo, evidenciou certa precipitação do CFP na regulamentação desta matéria, vez que as discordâncias dos debatedores com o CFP, e também entre eles, não dizem respeito a meras formalidades, mas a diferentes entendimentos do que seja a Psicologia Social como ciência e profissão, e dos impactos e efeitos de tal resolução. Assim, a partir da fala dos debatedores, surge um primeiro questionamento: trata-se, na Psicologia Social, da "discussão subjetiva dos fenômenos sociais", da "dimensão social do subjetivo" ou da "investigação e aplicação da Psicologia em uma pers- pectiva social"? Trata-se ainda, de um "ramo da Psicologia" ou "de um espaço de interseção entre a Psicologia e a Sociologia", não sendo, portanto, pertinente ao CFP, estender sua competência reguladora para um campo interdisciplinar. A discussão, como se vê, não se reduz aos aspectos burocráticos e normativos do exercício da profissão, mas diz respeito a uma problematização da separação entre o que seria da ordem do social e da ordem do subjetivo.

Outra questão de fundo é a própria especialização. O que é o especialista e que efeitos produz a transformação das áreas da Psicologia em Especialidades? É o psicólogo especialista um técnico, um gestor, um perito? Especialistas ou especialismos? Profissionais competentes e qualificados ou falas de podersaber, produzindo efeitos de desconhecimento? Lembro-me de ter presenciado, certa vez, um debate sobre o ensino e a pesquisa, no qual compareceram representantes da área da Psicologia no CNPQ e CAPES, quando nos foi dito que os professores de Psicologia deveriam se conscientizar que ensinar não era uma questão de "arte", "ofício" ou o que seja, mas uma questão "técnica" e que os Cursos de Psicologia deveriam começar a pensar em formar "gestores". Não posso deixar aqui de assinalar o mau estar que senti diante de tais afirmações, posto que ali mesmo, naquele momento, presenciava a redefinição dos objetos da Psicologia e da Educação, reduzidas ambas aos seus aspectos técnicos e de gestão, sem maiores cerimônias. Tais posicionamentos, ao serem feitos por órgãos normativos de ensino, pesquisa e profissão, não são sem efeitos, na medida em que subsidiam políticas de avaliação e credenciamento de cursos e de fomento à pesquisa. Assim, a questão do Especialista também requer uma discussão que não a reduza às demandas do mercado ou à defesa corporativa da profissão.

Posto estas colocações, passemos, brevemente, às falas dos debatedores. Representando o CFP, Odair Furtado ${ }^{1}$ afirmou que a política que define a concessão de títulos de especialistas tem aspectos positivos e negativos, sendo estes decorrentes da impossibilidade de um órgão como o Conselho atuar na contramão da dinâmica do capitalismo. $\mathrm{O}$ aspecto positivo constitui-se na possibilidade de interferir 
no campo dos cursos livres, onde, até então, ofereciase apenas um certificado de especialização. Definido esta política, a questão torna-se apenas a de sua gestão. Reconhece, no entanto, que a definição da área não ficou "das melhores".

Para o atual Presidente da ABRAPSO, Cornelis Stralen, a Psicologia Social não pode ser definida como um ramo da Psicologia. Assim, o CFP, ao definir a Psicologia Social como Especialidade da Psicologia, estendeu indevidamente sua competência reguladora para um campo interdisciplinar. Aponta o próprio Estatuto da ABRAPSO como promotor de ambigüidade, na medida em que define que um dos objetivos dessa Associação é o de desenvolver a Psicologia em uma perspectiva social no Brasil. Propõe que a resolução do CFP seja repensada à luz de tais considerações.

Discorrendo sobre as característica do contemporâneo, afirmam Neuza Guareschi e Simone Hüning, a inviabilidade de se continuar a pensar o conhecimento e a prática profissional dentro de fronteiras tão rigidamente delimitadas. O próprio CFP o reconhece, quando afirma não existir clareza sobre o que seria a identidade do psicólogo social, já que nem todos se reconhecem na definição e delimitação da área oferecida pelo Conselho. Lembro-me de um fato recente, ocorrido na cidade do Rio de Janeiro, onde a maior procura por um dos cursos de Especialização em Psicologia Jurídica foi de advogados e outros profissionais e não de psicólogos. Tal procura esbarrou, no entanto, na prerrogativa da atividade para o psicólogo.

Finalmente, Heliana Conde, ao trazer elementos históricos da criação da ABRAPSO, problematizando a separação entre social e subjetivo, pergunta o que teria se passado de lá para cá, possibilitando que a Psicologia Social tenha sido incluída nas especialidades e definida como a que "atua fundamentada na compreensão da dimensão subjetiva dos fenômenos sociais"? Terá sido o nosso silêncio, o que permitiu que os destinos da Psicologia Social tenha sido decidido em votação na Assembléia de Políticas Administrativas e Financeiras, do Sistema Conselhos de Psicologia?

Deixemos em aberto as perguntas. Que elas possibilitem a continuidade do debate.

\section{NOTA}

${ }^{1}$ texto não disponibilizado pelo palestrante para publicação.
Esther Maria de M. Arantes é pofessora do Programa de Pós Graduação em Políticas Públicas e Formação Humana da UERJ e professora do Departamento de Psicologia da PUC-Rio; Vice- Presidente da Abrapso e Membro da Comissão de Direitos Humanos do Conselho Federal de Psicologia. O endereço eletrônico da autoraé: arantes@rdc.puc-rio.br 